\title{
LPP wt Allele
}

National Cancer Institute

\section{Source}

National Cancer Institute. LPP wt Allele. NCI Thesaurus. Code C97611.

Human LPP wild-type allele is located in the vicinity of $3 q 28$ and is approximately $737 \mathrm{~kb}$ in length. This allele, which encodes lipoma-preferred partner protein, may play a role in cell motility and cell shape. A chromosomal translocation t(3;12)(q27-q28;q13-q15) of this gene with the HMGA2 gene is associated with lipoma and translocation $t(3 ; 11)(q 28 ; q 23)$ of this gene with the MLL gene is associated with acute monoblastic leukemia. 